\title{
“Living by their bodies ..." (Royal Charter 1067): prostitution in medieval England
}

\author{
Lesley Smith
}

\section{Christian rules and regulations}

According to scholars, the Romans left British shores in the 5 th century. However, some of the original Roman descendants had settled within local families and communities for over 300 years, resulting in a mix of cultures and beliefs. The early medieval period had begun and the Christian Church from the earliest days was taking a very great interest indeed in morality, both for the individual and society as a whole.

The rules of Christianity with regard to sexual practices were formidable, and much of the control was focused on degrees of pleasure and the perceived moral authority that the chaste enjoyed. Sexual purity came to symbolise an individual in control of temptation and therefore the devil. The Virgin Mary and the life of Christ were held up as the ultimate examples of the pure in Spirit - the Holy Grail personified - and almost as difficult to reach. Consider the 7th century Penitentials, which give advice as to suitable punishment for sexual misdemeanours. Fellatio between homosexuals could result in 4-7 years' penance. In the 13th and 14th centuries, all sins 'against nature', sodomy and zoophilia for example, were referred to the bishop. Confession must have been a fraught affair.

During the 8th century, a fascinating charter was drawn up by King Wihtred of Kent, which established a right of sanctuary for a brothel or number of brothels known as 'stewes' against prosecution from the civil or ecclesiastical courts. The area of London this charter protected was known as St Martin's le Grand.

Nearly 400 years later in 1067, this right was reconfirmed and extended to give immunity from such prosecutions to other areas of London. This may seem a rather impious and rapid piece of legislation for a conquering Christian king who only arrived in England late in the previous year. It was, however, yet another sound piece of business sense for King William the Conqueror, who is known to have owned a number of brothels in Normandy and Flanders. Soon after this piece of legislation, Flanders Bawdresses arrived with their girls and set up a series of stewes near the River Thames. This was one of the first properly planned prostitution businesses and a form of protection racket existed to look after it.

\section{Whorehouses and prostitution}

The name 'whorehouse' can be found in its original root form as 'hor-hus' in the year AD 1000 within the Glossorium of Archbishop Aelfric. The fact that a description can be found in such a work proves that such trading was well known.

In 1161, King Henry II, who transformed our legal system in England, gave the Bishop of Winchester the taxation of the whorehouses of Southwark, a lucrative and very busy piece of London. This gift would remain in the hands of the Winchester See for centuries to come.

J Fam Plann Reprod Health Care 2010; 36(1): 41-42

Tutbury Castle, Tutbury, UK

Lesley Smith, Curator

Correspondence to: Lesley Smith, Tutbury Castle, Tutbury, Staffordshire DE13 9JF, UK. E-mail: info@tutburycastle.com
Despite the Crown and Church's irrefutable link with prostitution, there was much thundering of hell and damnation from the pulpit. In fact, as the centuries went by, the rules of the Church became more and more demanding and complex, with the ecclesiastical courts holding extraordinary sway over a God-fearing society. Heresy and sexual sins, such as fornication or adultery, kept the courts and those who wished to witness such hearings (which, it seems, were many) very busy indeed. Cardinals, archbishops, bishops and priests all took care of the moral welfare of the community, whilst records show that many of them enjoyed the company of mistresses and courtesans. This is interesting in itself, for the Christian Church was very clear that those in religious office - whether man or woman - must be punished more harshly for poor morality than lay people. Meanwhile, the known illegitimate offspring of the fathers of the Christian Church often enjoyed high office, whilst an ordinary woman could be publicly humiliated for lewdness by showing her hair in public.

The lives of prostitutes are not well documented, but arguably better so than the other women of the day, because at least there are court cases to refer to, giving evidence of addresses, lifestyles and behaviour. Examples of rare published work such as Chaucer's Canterbury Tales also give us a tantalising glimpse of female lives. The tale of "The Wife of Bath" is particularly evocative of sexual exploits, adultery and desire.

\section{The merchants of venereal disease}

Brothels must have been a place of refuge, for even married sex was a sin if enjoyed during Lent or Advent or on other forbidden days; not to mention if your wife forgot herself and decided to change position to anything other than 'missionary' - all sinful matters.

At least in the stewe the woman was already lost. A highpainted creature with breasts on show and even perhaps allowing her hair to be seen. A woman who understood what pleasured a man - so that he could claim in confession that that he could not resist her sexual skills, which were so powerful as a result of her being in league with the devil. Maybe if the priest was under the See of the Bishop of Winchester the penitent did not have to worry at all!

To prove the link with the devil, a major Renaissance ecclesiastical court guidebook, the infamous Malleous Maleficarum, describes "from witchcraft comes carnal lust". This work acted as a handbook for courts to use in determining who really was a witch and not just a mad creature. It also reinforces the sinful nature of sex, which could, through the mortal sin of adultery and other such acts, result in eternal damnation in the fires of Hell. It is important to realise when considering medieval society's perception of sin and punishment that there was no such person as an atheist or even an agnostic. Heaven, Hell, Purgatory and Limbo were all places that existed with as much reality as did France. That of course also gives credence to the concept of the devil and his demons, fighting for our souls across the battle lines from God and the angels and saints.

If being 'naughty' is exciting then the idea of all that sin and possible punishment in the background must have made the sexual exploits of prostitutes very exciting indeed. The working girls appear in black and white woodcuts, pen 
drawings, and carvings bare-breasted and sitting on men's laps or offering drinks. They also appear in unexpected forms such as mermaids right up to the Tudor period, thereby suggesting they were not real women but some strange creature provided for sinful service to mankind.

The ranks of prostitutes have effectively not changed since ancient times: at the top of the league were the highclass, often educated expensive courtesans, then the youngish working-class girls, and finally the sixpenny whores, known as 'cockatrice' (also a mythical creature). In rural areas there were also the hedgerow female vagrants known as 'doxys', offering intercourse in a ditch or under a tree for bread and possibly the additional unexpected gift of an infectious disease that could prove fatal. As disease and age took beauty away, the girls tumbled down the league table and their price tag fell, just like modern professional footballers after a few too many seasons. It is thought that a large number of the girls didn't live much beyond the age of 30 years, not only because of illness but also because brothels can be dangerous places, well supplied with drink and everyone carrying knives hanging from a leather belt alongside rosary beads and a wooden cup. The atmosphere could be considerably heightened by the large sums of money lost in gambling, the second favourite way of spending money in such establishments.

The medieval prostitute: she may be a shadowy figure in history but she was definitely there...

\section{Future articles}

This article is the second of a series of three articles; the final article will take us forward in time from the Tudor period and will focus on the Georgian prostitute.

\section{Acknowledgement}

The author would like to thank Dr G Williams, British Museum, London, UK for his help and advice.

\section{Bibliography}

1 Bray, Alan. Homosexuality in Renaissance England. London, UK: Gay Men's Press, 1982.

2 Burford, EJ. London: The Synfulle Citie. London, UK: Robert Hale, 1990

3 Haynes, Alan. Sex in Elizabethan England. Stroud, UK: Sutton Publishing, 1997.

4 Browne, WF. The Importance of Women in Anglo Saxon Times. London, UK: SPCK Publishing, 1919.

5 Tannahill, Reay. Sex in History. London, UK: Abacus, 1989.

6 Burford, EJ and Wotton, Joy. Private Vices - Public Virtues. London, UK: Robert Hale, 1995.

\section{About the author}

Lesley Smith is currently a postgraduate student in the Centre for the History of Medicine of the University of Birmingham, where she is developing a PhD in obstetrics and gynaecology in early modern Britain. She holds an honorary degree for "services to history". She makes 200-300 public appearances a year and also works as a TV historian in the UK and abroad including the USA. Lesley is also Curator of Tutbury Castle in Staffordshire and is a member of the Society of Apothecaries of London and the Society of Medical Writers.

\section{BOOK REVIEWS}

Passionate Marriage: Keeping Love and Intimacy Alive in Committed Relationships. David M Schnarch. London, UK: WW Norton \& Co, 2009. ISBN-13: 978-0-39333-427-2. Price: £11.99. Pages: 448 (paperback)

This updated edition of the famous Passionate Marriage is a wonderful tool for couples and therapists to explore and integrate into their everyday lives. David Schnarch offers fresh examples and detailed analysis of cases so that we can understand his principles of ‘differentiation' fully.

This book is not an easy read but it invites the reader deeper into every chapter, encouraging reflection and understanding as one continues to explore the different themes that emerge. Therein lies the recipe for exploration of intimate relationships and the emotional turmoil such relationships bring. Being in an intimate relationship is the only way to develop such emotional maturity. As Schnarch says "marriage prepares one for marriage". Overcoming the difficulties and working with them through the 'crucible approach' is the way to a much more fulfilling understanding of the relationship itself, release of tensions and anxiety and thus realisation of one's sexual potential

Schnarch takes the reader through different case histories and sexual problems to illustrate his points. Each case has an analysis and allows the reader to reflect on learning from the previous case. He refers to later chapters when he talks about a new emerging theme and the reader can skip to the relevant parts if so desired. I preferred to read the book right through and then re-read some of the more complicated themes again.

This book will suit couples who enjoy reading and have some insight into their problems. It is unlikely to appeal to clients who do not really enjoy reflection or self-help, or those who find it difficult to connect with themes and case studies. It provides insight into a different way of working for therapists who deal with psychosexual problems. Towards the end of the book Schnarch also writes to tell clients what to expect from therapists who are properly trained in his technique and where to find such therapists This book is certainly a must-read for therapists clients and anyone in an intimate relationship who wants to fully explore their sexual potential and happiness.

Reviewed by Neelima Deshpande, MRCOG, MFSRH Staff Grade Doctor in Sexual and Reproductive Healthcare, Heart of Birmingham Teaching

Primary Care Trust, Birmingham, UK

Top Secret: Sexual Guidance for Married Couples (4th edn) (Arabic title: Sirri Lil Ghaya). Widad Lutah. Dubai Distribution Office, 2009. Price: 34.00 AED (around £7). Pages: 221 (paperback)

This is a much-needed book on a topic that has been buried under the shroud of religion, culture and tradition. The author is a marriage counsellor at the Family Guidance section in the Dubai Courthouse and is appropriately placed to write such a book.

The book is divided into seven chapters. The initial chapters deal with describing normal sexual behaviour as indicated in the Quran and Sunna (with examples from Prophet Muhammad's life), as well as the views of eminent Muslim scholars. There is a good description of the meaning of marriage in the Islamic cultural and religious context. The book urges the reader to understand the role of sex and sexual pleasure in a relationship. The author also addresses taboo subjects such as oral and anal sex from a religious as well as a cultural perspective.

The book talks openly about homosexuality in the Islamic world, where genders are rigorously separated. Many men have their first experiences with other men, which affects their attitude towards sex in marriage: "many men who had anal sex with men before marriage want the same thing with their wives, because they don't know anything else".

The book describes normal and abnormal sexual practices. It gives insight into practical sexual and relationship problems that affect individuals as well as couples. These are addressed through case studies that the author has been involved in, and the author attempts to offer possible explanations for the problems and also recommends solutions to them.

Although the language of the text is easy to read, there is use of formal Arabic words (e.g. use of terminology to name anatomical parts such as clitoris), which a layperson, and even a specialist, may find difficult to understand. [NB. It should be pointed out that the book is written in Arabic and is not currently available in any other languages.]

The book does not mention any other form of contraception than coitus interruptus. This could be because it is not within the scope of the book. However, the book does emphasise the function of marriage and sex as not only providing sexual pleasure but also, more importantly, that of reproduction. Therefore, other methods of contraception could have been mentioned.

The need for sex education and demystifying sexual practices by open discussion is the takehome message of this book - an important concept in a society where people are confused about moral issues with changing traditions.

We feel this book is a brave step in a challenging world of sexual taboos.

Reviewed by Angie Doshani, MRCOG Clinical Lecturer and Senior Registrar in Obstetrics and Gynaecology, University Hospitals of Leicester NHS Trust, Leicester, UK

\section{and Oudai Ali}

Specialist Registrar in Obstetrics and Gynaecology, Queen Alexandra Hospital, Portsmouth, UK 